Tarih Kültür ve Sanat Araştırmaları Dergisi

Revue des Recherches en Histoire Culture et Art

$$
\text { مجلة البحوث التاريخية و الثقافية والفنية }
$$

Vol. 6, No. 5, November 2017

Copyright (C) Karabuk University

http://kutaksam.karabuk.edu.tr

\title{
DOI: 10.7596/taksad.v6i5.1267
}

\section{Turkish Postmodernism through the "Second Wave" Paradigm: The Example of Creative Work by Hasan Ali Toptaş and Perihan Mağden}

\author{
Kseniya V. Grebenshcikova ${ }^{1}$, Alsu M. Nigmatullina ${ }^{2}$
}

\begin{abstract}
This paper describes the aspects of Turkish postmodernism of the "second wave", which is justified by an insignificant number of theoretical works and inadequate elaboration of studies concerning the representatives of Turkish postmodernism "second wave". The exception is represented by the works of Russian turkologists M.M. Repenkova and O.V. Kareva, who consider the features of the postmodern paradigm in their studies within the novelistics of the leading representatives of the Turkish postmodernism "second wave". The representatives of the "second wave" (Hasan Ali Toptaş, ìhsan Oktay Anar, Perihan Mağden, Kürşat Başar, etc.) were not the object of close research before, and therefore the consideration of their creativity as the next stage in the development of Turkish postmodernism is relevant. The "second wave" of postmodernism is characterized by the appeal to the literature of symbolic modeling in 1990s. During this period, the literature of postmodernism develops into a powerful trend, which becomes the predominant trend of the cultural life of Turkey in 2000s. It is worth noting that, if in the postmodern prose of 1980s was marked by the dominance of "lyrical stream", then in 1990s and 2000s the dominant trend was represented by narrative modification. Hasan Ali Toptaş, known for his mastery of language use, is regarded as one of the main representatives of the second wave of postmodern literature.
\end{abstract}

Keywords: Turkey, Postmodernism, Narrative, Intertextuality, Poetic style.

\footnotetext{
${ }^{1}$ Kazan Federal University, Institute of International Relations, History and Oriental Studies.

${ }^{2}$ Kazan Federal University, Institute of International Relations, History and Oriental studies. E-mail: alsunigmatullina@mail.ru
} 


\section{Introduction}

It should be noted that the priorities of the Turkish readers and critics who were brought up within the previous sharp-social literature are not changing immediately. In 1980s the works of postmodernists of the "first wave" produce the effect of a "burst bomb", but they remain misunderstood as a whole, are rejected by the reading public and literature researchers. Only in 1990s the attitude towards postmodernism begins to change gradually. During this period, with a general negative attitude toward this "Western phenomenon, harmful to national literature" critics, for example, already have an awareness that it needs to be studied. Then, there are also the first serious literary studies on the topic of postmodernism in 1990s by F. Akatlı, G. Aytaç, J. Agevit, A. Kabaklı, B. Moran, F. Nadjy, etc. (Repenkova, 2010). Postmodern romances-palimpsests become fashionable not only among the intellectual elite of Turkish society, but also among the urban educated population as a whole. The representatives of the "first wave" in postmodernism are replaced by prose writers of the "second wave" who turn to the literature of symbolic modeling during 1990s. (I.O. Anar, H.A. Toptaş, P. Mağden, K. Başar, N. Genç and others). The postmodern prose of that period developed into a powerful literary trend, which turned into a mainstream cultural life of the country during 2000s. At the same time, if the "lyrical stream" (B. Karasu, N. Eray, etc.) dominated in the Turkish postmodernist prose during 1980s, then the narrativistic modification prevails during 1990s - 2000s (I.O. Anar, H.A. Toptaş, P. Cure, etc.) (Kareva, 2014).

\section{Materials and methods}

The materials for the study were the materials of the biography and creative activity of writers, as well as postmodern novels that enable to identify the works by Hasan Ali Toptaş and Parihan Mağden as the representatives of Turkish postmodernism of the "second wave" during the analysis. The following research methods were used in the process of the work analysis:

Psychoanalytic method to understand subconscious and unconscious behavior of novel characters;

Biographical method establishes the links between an author's biography and novel features;

And postmodern method, in which a novel is understood as a discourse, and the artistic image is replaced by a simulacrum.

\section{Results and discussion}

H.A. Toptaş (born on October 15, 1958) is an outstanding Turkish writer. His first book of short stories "The Identity of a Smile" (Bir Gülüşün Kimliği) was published in 1987. A well-known Turkish scholar Yıldız Ecevit in his work "Postmodernist expansion in Turkish literature" (Türk Romanında Postmodernist Açılımlar) calls him "modernist postmodern", as well as "Kafka in Turkish literature" (Ecevit, 2016). Hasan Ali Toptaş, the winner of the literary award by Cevdet Kudret in 1999 for the novel "Thousand grim pleasures" (Bin Hüzünlü Haz), which is, on the one hand, a postmodern story in terms of pluralism, metaprose and intertextuality. On the other hand, it contains many Kafkaesque elements in terms of absurd, surreal and paradoxically secular reality description.

Hasan Ali Toptaş, who is considered one of the leading authors of modern Turkish literature, draws attention by his style, in particular. Academic studies and criticism in the novels by Toptaş usually emphasize this unique poetic style. However, its origins and structure have not been analyzed yet. Toptaş strengthened more his poetic style in his two last novels "Thousand grim pleasures" (Bin Hüzünlü Haz) and "The East Drowsens" (Uykuların Doğusu) and thus he transformed the narrative discourse into a literary image. Despite the postmodern features, which are usually attributed to the writer, Toptaş style takes its roots in modernism in accordance with the concept of reality and a reader's assumption. The author 
focuses on the complex and contradictory reality of an individual and presupposes a qualified / a wellprepared reader regarding the concept of reality and the transformation of a reader's assumption in modernist aesthetics. The discourse was isolated from the interference of the conscious "I" to some extent and aimed at the manifestations of consciousness reflections in the novels by Toptaş. Narrative discourse, which is far from unity and continuity, indicates space and time with extraordinary aspects, accumulating grotesque and surreal images. Thus, an imitative unity of a word and a thing is destroyed, and the concept of reality becomes an aesthetic representation of existence in mind. Linguistic discourse strategies that transform each component of a narrative into a literary image are the main results of this study.

The novel "Waste" ( $\mathrm{Heba}$ ) is the first book by H.A. Toptaş translated into English. It tells the story of a middle-aged anti-hero Turk Ziya Kul, persecuted by the tragic death of his wife and the unborn child, as well as an experienced military terrorizing the Syrian border. The story by Toptaş about Ziya Kul trauma, depicts the silent erosion of the hero's soul in a chaotic world, controlled by the mentality of the crowd, poverty, ignorance and cruel, aggressive military culture.

The center of the novel is represented by Mr. Ziya's final and tragic attempt to find peace in life. But the inner turmoil, suffering and anguish of the protagonist will follow him everywhere, and his transfer to the Edenic village Yazıköy will not save him. Sleep, memory and reality flow into each other in the narrative when feelings go out of order (smells are heard, sounds are seen). This is most clearly expressed in the first third of the book, in which a reader is exposed to almost 100 pages of Ziya's dreams.

A popular and versatile Turkish writer H.A. Toptaş cultivates his own style. His narrative technique, especially his use of metaphor, dreams, allegories and folklore narrative can be fascinating sometimes, but some of these technical and stylistic components remain problematic. In addition to its invigorating lifelessness ("It's so, but it's very strange," said Mr. Ziya, puzzled, "It's impossible that you know all this") (Toptaş, 2014), he manages to treat the reader with a feeling close to contempt, providing clear words with superfluous adjectives and adverbs: "Just do not lie there, time to get up!" Mrs. Nurgül said in a reproachful voice; "He exclaimed being in a shock:" They found me!" (Toptaş, 2014). This is exactly the type of the letter that appears when indulgence towards a reader is combined with some disbelief due to language.

One page has such diverse lines as "lose your mind", "straw that broke the camel's back", "at the end of our acute mind", "do not know the boundaries", "the sands of time", "rush like the wind". They are joined by all kinds of thoughtless buildings (birds have "beady eyes", houses "buzz like a hive", people wait "with bated breath" and exchange with "knowing views") (Toptaş, 2014).

Also the book has a lot of "sudden" actions. Sometimes we are told about the surprise twice, as in the sublime sentence "suddenly they all stopped abruptly" (Toptaş, 2014). Sometimes things get even more immediate: "His mind suddenly slipped to the Syrian border, and then, just as suddenly, a shaft of light slipped" (Toptaş, 2014).

Thus, the novels by Hasan Ali Toptaş are filled with a unique cultivated poetic style. His postmodern code, and especially the use of metaphor and allegory, is not clear to every reader.

Speaking of the "Second Wave" of postmodernism in Turkish literature, one is doomed to pay attention to the work by Perihan Mağden. Orhan Pamuk, the well-known writer of Turkey who won the Nobel Prize in Literature in 2006, told about P. Mağden as "one of the most inventive and outspoken writers of our time" in the Guardian (June 3, 2006). O. Pamuk emphasizes the author's manner and style, "the way she twists and turns the Turkish language, the delight she takes in the thrust and pull of popular culture, and 
her brilliant forays into subjects that everyone thinks about... these have earned her the love of her readers and the respect of her fellow writers" (ibid.).

Her novel "Escape" (Biz Kimden Kaçıyorduk Anne) published in 2007 was considered one of the best Turkish novels of that year. Her previous novels were the following ones: "Two girls" (iki Genç Kızın Romanı), "The murders of messenger boys" (Haberci Çocuk Cinayetleri) and "Companions" (Refakatçi). Her latest collection of non-fiction literature is called "Political Essays".

The book by P. Mağden "The murders of messenger boys" is a detective of absurdity. The inhabitants of the city have bizarre names and have no less bizarre occupations. The city does not have a name; the inhabitants correlate it with a labyrinth by themselves. In this city a genetic experiment was carried out many years ago to deduce the ideal messenger boys. Due to special drugs, these boys look like six-yearolds, although in fact they can be much older. They reason like small robots. The protagonist, who returned from the journey, has to take up the investigation of these messenger boys murders.

The story about the murders is only the part of the plot, which can be classified as magical realism. The novel was translated into many languages. The book by P. Mağden attracts the attention of "advanced" literature fans. The main meaning of the novel is not the investigation of local pride murders - artificially created impeccable boys-messengers. Main thing in the novel is the absurd atmosphere of the labyrinth city, where everything around is not what it seems.

"Milet Books" publishing house, calling P. Mağden "a popular and an innovative Turkish author", describes the novel as "a gloomy, comic, irreverent and soporific story, the study of humanity infinite absurdity and its futile attempts to create perfection skilfully wrapped in the mystery of a murder" (Hamer, 2009).

Maureen Freely responds to the novel "The murders of messenger boys" as follows in the magazine about the Turkish culture "Cornucopia": "The actions of the novel take place in the city that feels like Russian, but inhabited by the residents with Chinese names, full of apathy of the nineteenth century, but with the references to Hollywood and overshadowed by the villainous fertility expert, it is difficult to classify, it is impossible to suppress" (Freely, 2009).

P. Mağden is the writer who deals with journalism. She writes about politics, military affairs, human rights, homosexuality and the general human condition in Turkey. She was tried and acquitted because she called for the permission to refuse from military service because of moral principles.

\section{Conclusion}

The "second wave" of Turkish literary postmodernism is a new trend in the literature of Turkey at the turn of the 20th and the beginning of the 21st century. The representatives of this group are a small group of writers who started their creative activity in the 1990s of the 20th century. The "second wave" of postmodernism is characterized by the appeal to the literature of symbolic modeling in 1990s. The literature of postmodernism develops in a powerful current, which becomes the predominant trend of the cultural life of Turkey in 2000s.

At the moment, Turkish literature is in a constant development and popularization, which contributes to the increase and the diversity of themes and techniques used by the authors. Having studied the stages of postmodern trend emergence and development, we can draw the following conclusions:

The discoverer of the Turkish postmodernism was Oguz Atay with the novel "The Expendables" (Tutunamayanlar) in 1970. At that time, the intellectuals of the Turkish novelists did not know postmodern or modern literature. Therefore, Oguz Atay's novel provoked conflicting criticism. The next novel, which turned out to be equally incomprehensible to critics, was Orhan Pamuk's novel "The Black 
Book" (Kara Kitap), released in 1990. Even though O. Pamuk's novel was recognized in European countries, and Turkish critics took a different look at social realism. After that, postmodernism acquired a different perception and became a popular trend in Turkey.

Thus, after the study of postmodernist writers of the "second wave", we came to the conclusion that their creative style is difficult and incomprehensible in some cases for an unprepared reader. At the moment, Turkish literature is in a constant development and popularization, which contributes to the increase and the diversity of themes and techniques used by the authors. This was facilitated by the coup d'etat in Turkey in September of 1980. The country changed its view on the structure of secular society, which was hardly perceived by Turkish writers and gave rise to a feeling of despair and pessimism in the creative environment. At the same time, during this period there was an active informatization and computerization of the Turkish people. All this contributed to the emergence and the development of Turkish postmodernism. Hassan Ali Toptaş, ìhsan Oktay Anar, Perihan Mağden, Kürşat Başar, and Elif Shafak turn to such postmodern methods as pluralism, metaprose, intertextuality, multilevel nature, magical realism and tabulation in their works. By their works they raise acute social issues. The writers of the second wave resort to narrative modification and symbolic modeling.

\section{Acknowledgements}

The work is performed according to the Russian Government Program of Competitive Growth of Kazan Federal University.

\section{References}

Ecevit, Y. (2016). Türk Romanında Postmodernist Açılımlar. Istanbul: iletişim.

Hamer, R. (2009). Millet Books "The Messenger Boy Murders". Istanbul: Iletişim.

Kareva, O. V. (2014). Merry demolition: postmodern paradigm in the novelism by Ihsan Oktay Anar. Moscow: MBA publishing house.

Pamuk, O. (2006). A question of conscience: Orhan Pamuk defends Turkey's controversial female columnist. Guardian. June, 3.

Repenkova, M. M. (2010). Rotating mirrors: postmodernism in Turkish literature. Institute of Asian and African Studies. Moscow State University named after M.V. Lomonosov. Middle Eastern Literature.

Repenkova, M. M. (2016). Turkish Literature at the turn of the twenty-first century: basic paradigms. The Institute of Asian and African Studies, Moscow State University named after M.V. Lomonosov. Moscow: Science, Eastern Literature.

Toptaş, H. A. (2014). Heba. Istanbul: Iletişim.

Üster, C. (2009). Yeryüzü kitaplığı. Radikal Gazetesi. 